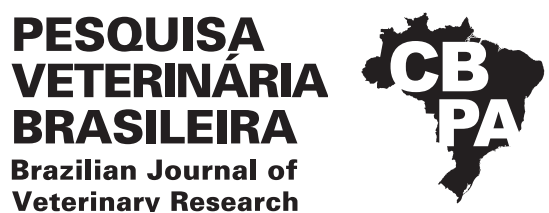

Pesq. Vet. Bras. 41:e06882, 2021

DOI: 10.1590/1678-5150-PVB-6882

Original Article

narv Research

Livestock Diseases

ISSN 0100-736X (Print)

ISSN 1678-5150 (Online)

\title{
Spontaneous poisoning by Cestrum intermedium in dairy cattle ${ }^{1}$
}

\author{
Camila B. Pohl ${ }^{2 *(D)}$, Márcia E. Hammerschmitt ${ }^{2}$ (D), Franciéli A. Molossi² (D), \\ Marina P. Lorenzett ${ }^{2}$, Ronaldo M. Bianchi ${ }^{2}$, Márcia Vignoli-Silva ${ }^{3}$, \\ Samuel Bianchetti ${ }^{4}$, Welden Panziera ${ }^{2}$ (D), Claudio S.L. Barros ${ }^{5}$ (i), \\ Saulo P. Pavarini ${ }^{2}$ (D) and David Driemeier ${ }^{2}$ (D)
}

\begin{abstract}
Pohl C.B., Hammerschmitt M.E., Molossi F.A., Lorenzett M.P., Bianchi R.M., Vignoli-Silva M., Bianchetti S., Panziera W., Barros C.S.L., Pavarini S.P. \& Driemeier D. 2021. Spontaneous poisoning by Cestrum intermedium in dairy cattle. Pesquisa Veterinária Brasileira 41:e06882, 2021. Setor de Patologia Veterinária, Departamento de Patologia Clínica Veterinária, Faculdade de Veterinária, Universidade Federal do Rio Grande do Sul, Av. Bento Gonçalves 9090, Prédio 42505, Porto Alegre, RS 91540-000, Brazil. E-mail: cacabpohl@gmail.com

Acute hepatotoxicity caused by plants poisoning is responsible for economic losses in farm animals in Brazil. Reports of Cestrum intermedium natural poisoning in cattle are not commonly described in Rio Grande do Sul (RS). This study aimed to document an outbreak of spontaneous C. intermedium poisoning in dairy cattle in the Central-Eastern Mesoregion of RS. Three nine-month-old Holstein and Jersey heifers were affected after they were placed in a small paddock with shortage forage. In this area, specimens of $C$. intermedium Sendtn with signs of consumption were observed. Morbidity and lethality rates were $100 \%$ and clinical courses ranged from 9 to 12 hours. At post mortem examination of the three heifers, there was predominance of acute liver lesions. The liver was moderately enlarged and on the cut surface there was a marked accentuation of the lobular pattern and hemorrhage. Inside the rumen, partially digested $C$. intermedium Sendtn leaves were observed. The histological aspects of the liver were mostly centrilobular coagulative necrosis and hemorrhage, frequently extended to the midzonal region. The immunohistochemistry technique was performed, in which the polyclonal antibody caspase 3 was used in liver fragments. Moderate to marked immunolabeling was observed in the cytoplasm and nucleus of hepatocytes, predominantly on the periphery of areas of hepatic necrosis indicating cell apoptosis. The diagnosis of $C$. intermedium Sendtn poisoning in dairy cattle in this study was based on epidemiological, clinical and anatomopathological findings. Since the $C$. intermedium poisoning is uncommon in dairy cattle, we are describing it for the first time in the Central-Eastern Mesoregion of RS, and represents a differential diagnosis of other acute toxic liver diseases in cattle.
\end{abstract}

INDEX TERMS: Spontaneous poisoning, Cestrum intermedium, dairy cattle, apoptosis, cattle disease, caspase, hepatotoxicity, pathology, toxic plants, veterinary toxicology.

\footnotetext{
${ }^{1}$ Received on March 25, 2021.

Accepted for publication on April 9, 2021

${ }^{2}$ Setor de Patologia Veterinária, Departamento de Patologia Clínica Veterinária, Faculdade de Veterinária, Universidade Federal do Rio Grande do Sul (UFRGS), Av. Bento Gonçalves 9090, Prédio 42505, Porto Alegre, RS 91540-000, Brazil. *Corresponding author: cacabpohl@gmail.com

${ }^{3}$ Universidade Federal de Ciências da Saúde de Porto Alegre (UFCSPA), Rua Sarmento Leite 245, Centro Histórico, Porto Alegre, RS 90050-170, Brazil.

${ }^{4}$ Veterinarian, Forquetinha, RS, Brazil

${ }^{5}$ Faculdade de Medicina Veterinária e Zootecnia (FMZV), Universidade Federal de Mato Grosso do Sul (UFMS), Av. Senador Filinto Müller 2443, Campo Grande, MS 79074-460, Brazil.
}

RESUM0.- [Intoxicação espontânea por Cestrum intermedium em bovinos de leite.] Intoxicações por plantas que causam hepatotoxicidade aguda são responsáveis por prejuízos econômicos em animais de produção no Brasil. Relatos de intoxicações naturais por Cestrum intermedium em bovinos não são comumente descritos no Rio Grande do Sul (RS). Este trabalho teve como objetivo documentar um surto de intoxicação espontânea por $C$. intermedium em bovinos leiteiros ocorrido na região Centro-Oriental do RS. Três bovinos com nove meses de idade, das raças Holandês e Jersey, foram acometidos depois de serem introduzidos em 
um pequeno piquete com escassez de forragem. Nessa área foram observados exemplares de Cestrum intermedium Sendtn com sinais de consumo. As taxas de morbidade e letalidade foram de $100 \%$ e os cursos clínicos variaram de 9 a 12 horas. $\mathrm{Na}$ necropsia dos três bovinos, observou-se predomínio de lesões hepáticas agudas. 0 fígado dos animais acometidos estava moderadamente aumentado de tamanho e na superfície de corte havia marcada acentuação do padrão lobular e hemorragia. Na abertura do rúmen, foram observadas folhas de Cestrum intermedium Sendtn parcialmente digeridas. Histologicamente, o fígado apresentava necrose coagulativa centrolobular e hemorragia. Frequentemente, essas alterações se estendiam para a região mediozonal. Foi realizada a técnica de imuno-histoquímica, na qual utilizou-se o anticorpo policlonal caspase 3 em fragmentos de fígado. Notou-se marcação moderada a acentuada em citoplasma e núcleo de hepatócitos, predominantemente na periferia das áreas de necrose hepática indicando apoptose celular. 0 diagnóstico de intoxicação por Cestrum intermedium Sendtn nos bovinos leiteiros desse estudo, foi realizado com base nos achados epidemiológicos, clínicos e anatomopatológicos. A intoxicação por $C$. intermedium é incomum em bovinos leiteiros, sendo descrita pela primeira vez na região centro oriental do RS e representa um diagnóstico diferencial de outras hepatopatias tóxicas agudas.

TERMOS DE INDEXAÇÃO: Intoxicação espontânea, Cestrum intermedium, bovinos de leite, apoptose, doença de bovinos, caspase, hepatotoxicidade, patologia, plantas tóxicas, toxicologia veterinária.

\section{INTRODUCTION}

Cestrum species are widespread in America tropical and subtropical areas, and are considered important causes of deaths in cattle in Brazil, due developing of acute hepatotoxic lesions (Kissemann \& Groth 2000, Tokarnia et al. 2012). Among the 250 species of Cestrum described, those that have already been described as toxic to cattle in Southern Brazil include: Cestrum intermedium Sendtn. (Furlan et al. 2008, Bandarra et al. 2009, Wouters et al. 2013), Cestrum corymbosum var. hirsutum (Gava et al. 1991) and Cestrum parqui L'Hér (RietCorrea et al. 1986). In other regions of Brazil (Southeast, Center-West and coast of the Northeast), Cestrum laevigatum is one of the most important species (Tokarnia et al. 2012). Cestrum intermedium (Solanaceae) is a perennial shrub that causes spontaneous poisoning in farm animals, mainly from the state Santa Catarina, Brazil. The poisoning is commonly associated with forage shortages an or overcrowding (Gava et al. 1996, Soares et al. 2007, Vignoli-Silva 2009, Tokarnia et al. 2012, Wouters et al. 2013). C. intermedium is found in fertile and wet lands, and can reach up to five meters in height (Soares et al. 2007, Lorenzi 2008, Tokarnia et al. 2012). It is popularly known as "coerana", "mata-boi", "peloteira negra" and "erva-de-tinta" (Gava et al. 1996, Kissemann \& Groth 2000, Lorenzi 2008, Tokarnia et al. 2012). The toxicity of $C$. intermedium is widely known, however, the toxic principle remains undetermined (Kissemann \& Groth 2000).

The clinical course is usually peracute, occurring within nine to 17 hours after the plant's ingestion. Signs include apathy, anorexia, rough hair coat, muscle tremors, staggering, dry snout, abundant salivation, rumen atony, aggressively, groans, decubitus, paddling movements, and death (Furlan et al. 2008, Bandarra et al. 2009, Wouters et al. 2013). Reports of natural poisoning in cattle by $C$. intermedium are not commonly reported in Rio Grande do Sul (RS). There is a single outbreak of $C$. intermedium poisoning in cattle described in that state (Bandarra et al. 2009). In dairy cattle poisonings by species of Cestrum are rare in Brazil (Coutinho et al. 2013). Therefore, we aim to report an outbreak of spontaneous $C$. intermedium poisoning in dairy cattle in the Central-Eastern Mesoregion of RS.

\section{MATERIALS AND METHODS}

The collection of epidemiological data, the observation of clinical signs and the necropsy of three heifers were carried out in visits to the farm where the disease outbreak occurred. Organ samples were collected and fixed in 10\% formalin and processed for histological evaluation and stained using hematoxylin and eosin (HE). In addition, a voucher of Cestrum intermedium was collected and deposited in the "Herbário ICN" of the "Universidade Federal of Rio Grande do Sul" and registered under the number: "ICN 203129".

Immunohistochemistry (IHC) was applied to formalin-fixed paraffin-embedded liver tissue fragments using a caspase 3 (CASP3) rabbit polyclonal antibody $\left(\right.$ Biorbyt $\left.^{\circledR}\right)$. Endogenous peroxidase was blocked out by incubating the slides in a 10\% hydrogen peroxide solution and methanol. The antigenic recovery was performed with citrate $\mathrm{pH} 6$, for 40 minutes at $90^{\circ} \mathrm{C}$, in a pressure cooker. The sections were treated with $5 \%$ skimmed milk $\left(\right.$ Molico $\left.^{\circledR}\right)$ diluted in distilled water for 30 minutes to decrease the background due to nonspecific chemical bonds. The slides were incubated with CASP3 at 1:700 dilution in phosphate-buffered saline (PBS) overnight at room temperature (approximately $25^{\circ}$ to $27^{\circ} \mathrm{C}$ ). Detection was performed with a MACH4 polymer kit using the chromogen used AEC $\left(D_{A K O}{ }^{\circledR}\right)$, romulin. The sections were counterstained with Harris' hematoxylin for less than 1 minute. Successive sections were incubated only in PBS and served as negative control; liver sections were used as positive control.

\section{RESULTS}

In June 2019, three nine-month-old Holstein and Jersey heifers were weaned and placed in a small paddock where they were fed with low forage availability, and supplemented with low amounts of corn silage and commercial feed. The farm was located in Forquetinha, RS (29²2'55" South 52 $27^{\prime} 27^{\prime \prime}$ West). The owner reported that cattle were fine in the night before the onset of clinical signs; in the morning, two heifers were found dead, and another was in sternal decubitus with muscle tremors groans and paddling movements; it died two hours later. In the pasture where cattle were held there were abundant adult specimens of Cestrum intermedium (with a maximum height of two meters) with signs of being consumed by the cattle (Fig.1).

In post mortem examination, the three cadavers were dehydrated, and the rumen contents had partially digested leaves mixed in the rumen content similar to the $C$. intermedium leaves found in the paddock (Fig.2). Also, the ruminal content presented a strong odor, similar to the crushed fresh leaves of $C$. intermedium. At necropsy of the three cattle there was a predominance of acute liver lesions, characterized by moderately swollen and rounded edges. There was a marked accentuation of the lobular pattern on the cut surface, characterized by dark red centrilobular areas surrounded by lighter areas (Fig.3). 
The lungs were non-collapsed and diffusely red; there was a moderate amount of white foam in the trachea and multifocal petechiae on the epicardium. No other toxic plants or agents known to cause acute liver damage were present on the farm.

Histologically, there was marked centrilobular hepatocellular coagulative necrosis and hemorrhage. These changes frequently also extended to the midzonal region of the lobule and occasionally forming bridges (Fig.4). Hepatocytes immediately surrounding the necrotic area had marked vacuolar degeneration. Extrahepatic histological changes included moderate multifocal hemorrhage in the endocardium, extending to the myocardium, and diffuse moderate pulmonary edema.

The IHC using CASP3 revealed moderate to strong marking in the cytoplasm and nucleus of hepatocytes, predominantly those on the periphery of hepatic necrosis, in the interface between necrotic tissue and viable hepatocytes (Fig.5).

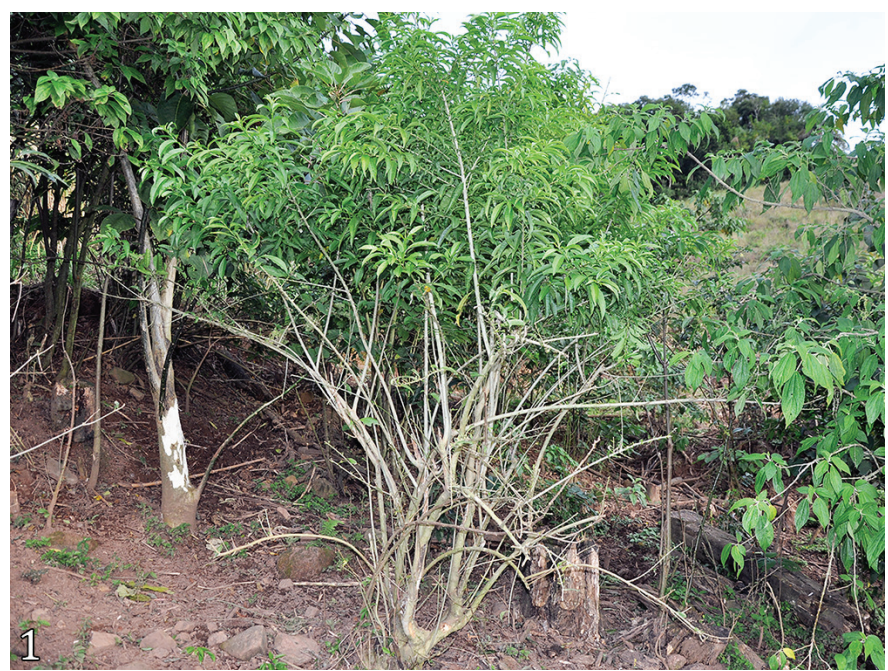

Fig.1. Specimens of Cestrum intermedium with evidence of consumption.

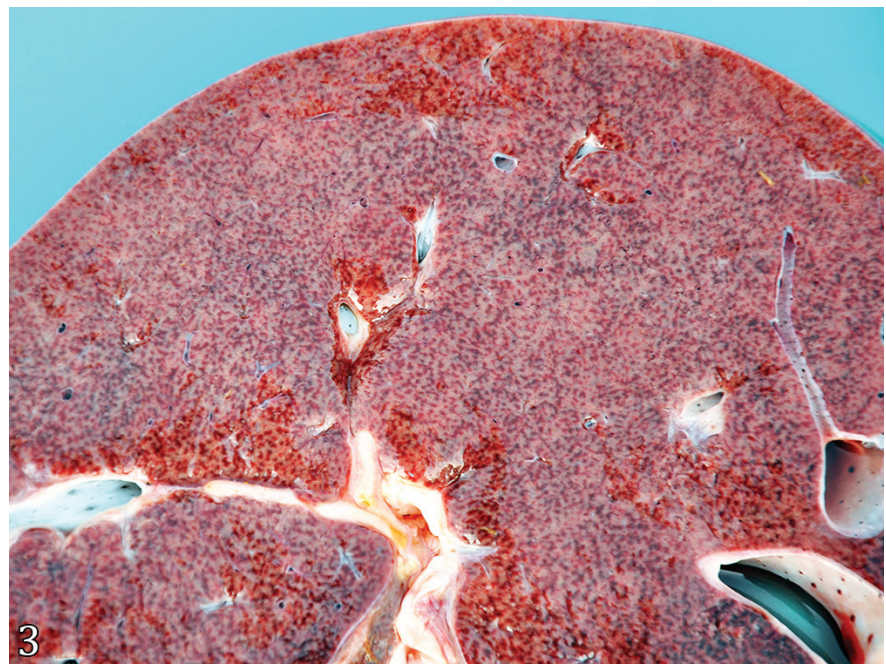

Fig.3. Spontaneous poisoning by Cestrum intermedium in heifer. Liver with accentuation of the lobular pattern. There are dark red areas interspersed with lighter areas in the middle of the parenchyma.

\section{DISCUSSION}

The diagnosis of Cestrum intermedium poisoning in dairy cattle of this study was based on epidemiological, clinical, and anatomopathological findings. Since there were abundant specimens of $C$. intermedium in the paddock, we assumed this certainly allowed grazing access to the leaves, which had visible signs of being consumed. This epidemiological evidence contributes significantly to the diagnosis of intoxication in these cases (Bandarra et al. 2009). Outbreaks of intoxication by $C$. intermedium have been reported in the west of Santa Catarina, northwestern and northeastern RS, southwestern of Paraná, and northern of Argentina (Bandarra et al. 2009, Tokarnia et al. 2012). This report documents for the first time the intoxication in cattle by C. intermedium in the Central-Eastern Mesoregion of RS.

Cestrum intermedium ingestion by cattle generally tends to occur in periods of forage scarcity, especially in winter (Bandarra et al. 2009, Tokarnia et al. 2012, Wouters et al. 2013). This is in line with our findings since the outbreak occurred in June

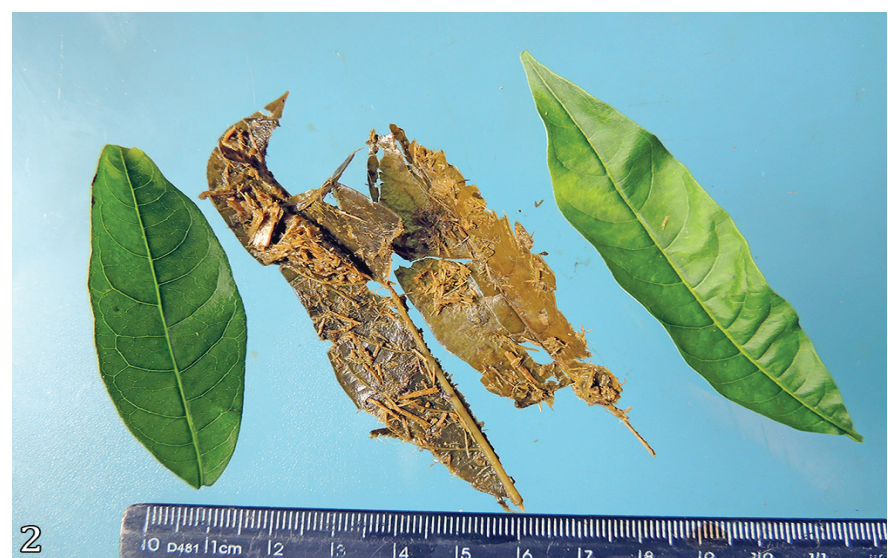

Fig.2. At the center of theimage are two leaves sampled from the heifers' rumen. Next to them, for comparison, are two leaves of Cestrum intermedium from the paddock where the poisoned heifers were grazing.

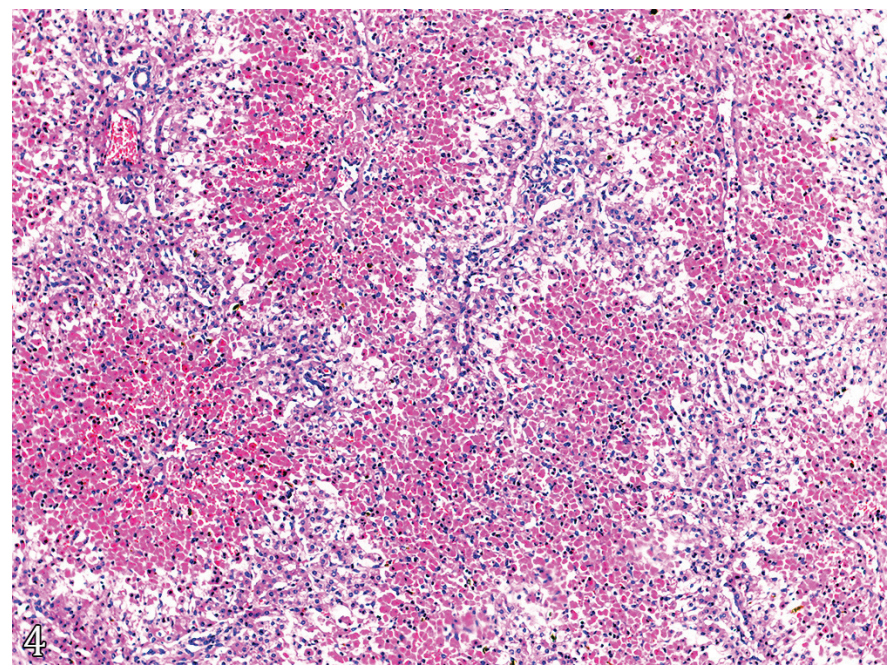

Fig.4. Spontaneous poisoning by Cestrum intermedium in heifer. Liver with hepatocellular, centrilobular to midzonal necrosis and hemorrhage, and occasionally forming bridges. Remaining hepatocytes are observed near the periportal areas. HE, obj.10x. 
and the cattle were housed in a paddock with poor forage availability and supplemented with low amounts of silage and commercial feed. The toxic dose of $C$. intermedium varies from 25 to $30 \mathrm{~g} / \mathrm{kg}$ of body weight (Gava et al. 1996, Soares et al. 2007, Vignoli-Silva 2009, Tokarnia et al. 2012). In this outbreak, it was impossible to estimate the amount ingested by the heifer since they had free access to the plant.

In the current outbreak, it was not possible to determine the time between ingestion of the plant and the heifer's death. However, the previous night the cattle had eaten typically and showed no signs of intoxication. On the following morning, two cattle were found dead, and another was recumbent, moaning with muscle tremors, and paddling movements, which indicates a peracute clinical course and is in line to what is reported by other authors (Rissi et al. 2007, Furlan et al. 2008, Bandarra et al. 2009, Wouters et al. 2013). Morbidity, mortality, and lethality rates of $100 \%$ were observed. Generally, the morbidity rate can vary from $5-30 \%$; the mortality rate may be up to $100 \%$ (Furlan et al. 2008, Bandarra et al. 2009, Riet-Correa et al. 2009, Wouters et al. 2013). The high morbidity in the current outbreak may be associated with the low number of cattle present in the area with the plant.

The gross and histological liver lesions induced by $C$. intermedium poisoning observed in the heifers from the current outbreak are characteristic of acute toxic liver disease and similar to those reported in the literature (Rissi et al. 2007, Furlan et al. 2008, Bandarra et al. 2009). Those features associated with epidemiological data allow for a definitive diagnosis of $C$. intermedium intoxication. The main gross findings in the heifer of the current outbreak involved the liver and were characterized by hepatomegaly and marked lobular pattern. Extrahepatic changes described in cases of $C$. intermedium intoxication in cattle are edema of the gallbladder wall and the initial portion of the duodenum, retraction of the eyeballs due to dehydration, disseminated hemorrhages, and dryness of the contents of the omasum, colon, and rectum (Gava et al. 1996, Bandarra et al. 2009). In the present outbreak, few extrahepatic changes were found, which may be due to the peracute clinical course.

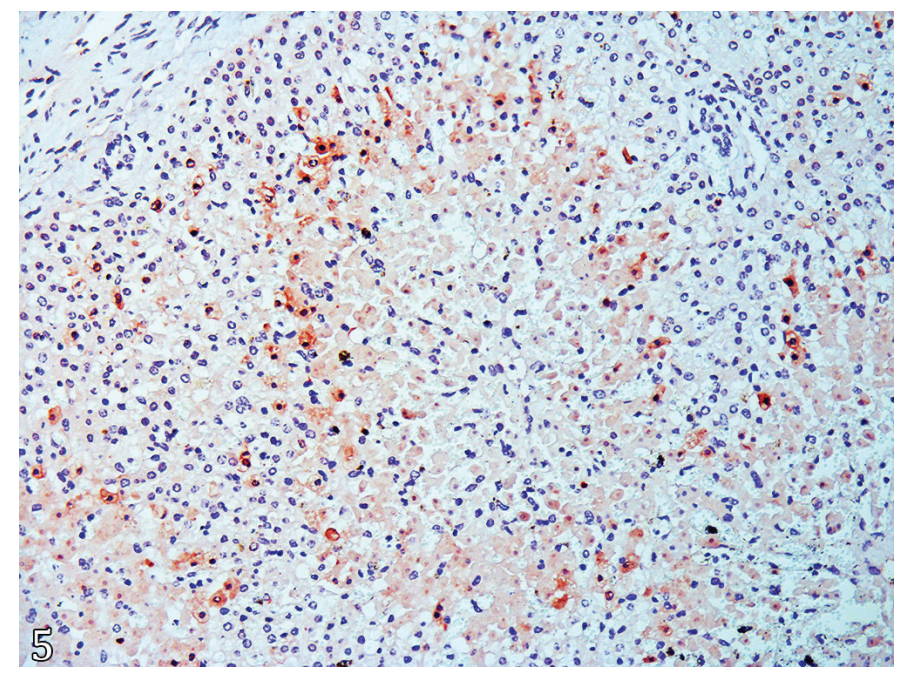

Fig.5. Spontaneous poisoning by Cestrum intermedium in heifer. Liver whit moderate to strong immunolabeling in the cytoplasm and nucleus of hepatocytes located in the periphery of necrotic areas for CASP3. IHC, obj.20x.
Microscopically, marked hepatic necrosis was observed, predominantly centrilobular. Acute liver injuries of toxic origin (Rissi et al. 2007, Tokarnia et al. 2012), as the present case, induce a pattern of centrilobular necrosis (Plumlee 2004, Scherk \& Center 2010) attributed to the high activity of mixed-function enzymes in hepatocytes located close to the central vein. This region is considered the most active in the biotransformation of toxic substances (Plumlee 2004, Rissi et al. 2007). Besides, the centrilobular portion of the lobes receives less oxygenated blood, making it more susceptible to hypoxia (Plumlee 2004, Rissi et al. 2007).

When there is an injury to hepatocytes, mitochondria dramatically decrease energy production (adenosine triphosphate), leading to lipid ß-oxidation. The consequences are the accumulation of intrahepatic lipid (microvesicular steatosis) and further reduced energy production, with generation free radicals, such as superoxide (Brown et al. 2017). The findings pathogenesis, since the intracytoplasmic microvesicles were in the hepatocytes adjacent to the necrotic areas, suggesting that this is the first hepatic change to occur. Besides, damaged mitochondria release cytochrome C enzymes, activating apoptosis, and hepatocyte necrosis (Brown et al. 2017). This information was also verified in the present study, where apoptosis was observed in the peripheral areas of centrilobular necrosis, highlighted by IHC. This apoptotic immunostaining suggests that necrosis and apoptosis are associated with centrilobular lesions of toxic origin and indicate that apoptosis may precede necrosis due to the increasing centrilobular lesions pattern. Caspase 3 IHC was previously described by Navarro et al. (2017), for imunolabeling of apoptotic cells in peripheral areas to liver necrosis caused by Clostridium novyi type D (bacillary hemoglobinuria) in cattle.

In the differential diagnosis of intoxication by $C$. intermedium in RS, other toxic causes of liver necrosis in cattle must be considered, such as Xanthium cavallinesii (Driemeier et al. 1999), Cestrum parqui (Riet-Correa et al. 1986), Myoporum laetum (Raposo et al. 1998), Dodonaea viscosa (Colodel et al. 2003) and Perreyia flavipes larvae (Tessele et al. 2012). Those were ruled out based on epidemiological evidence.

\section{CONCLUSION}

The report of specimens of Cestrum intermedium in the CentralEastern region of RS is essential to veterinary practitioners and pathologists alike consider the intoxication by this hepatotoxic plant in the differential diagnosis of acute toxic liver diseases in cattle in this region. Thus, awareness of this condition may help in its control avoiding livestock losses.

\begin{abstract}
Authors' contributions.- C.B. Pohl, M.E. Hammerschmitt, F.A. Molossi, M.P. Lorenzett, R.M. Bianchi, M. Vignoli-Silva, S. Bianchetti, W. Panziera, C.S.L. Barros, S.P. Pavarini and D. Driemeier contributed to the collection of the samples, made a substantial contribution to the gross, plant identification and histopathological analysis, drafted and revised the manuscript and its final version.
\end{abstract}

Acknowledgments.- The authors thank the "Conselho Nacional de Desenvolvimento Científico e Tecnológico" (CNPq) and "Coordenação de Aperfeiçoamento de Pessoal de Nível Superior" (CAPES) for supporting this study. Also, the authors thank Dra. Marcele Betim Bandinelli for her valuable help in standardizing and making the IHC slides.

Conflict of interest statement.- The authors declare having no conflicts of interest. 


\section{REFERENCES}

Bandarra P.M., Bezerra Júnior P.S., Corrêa A.M.R., Pedroso P.M.O., Raymundo D.L. \& Driemeier D. 2009. Intoxicação natural por Cestrum intermedium em bovinos no Rio Grande do Sul, Brasil. Ciência Rural 39(1):262-265. <https://dx.doi.org/10.1590/S0103-84782008005000050>

Brown D.L., Van Wettere A.J. \& Cullen J.M. 2017. Hepatobiliary system and exocrine pancreas, p.412-470. In: Zachary J.F. (Ed.), Pathologic Basis of Veterinary Disease. 6th ed. Elsevier, St Louis.

Colodel E.M., Traverso S.D., Seitz A.L., Correa A., Oliveira F.N., Driemeier D. \& Gava A. 2003. Spontaneous poisoning by Dodonea viscosa (Sapindaceae) in cattle. Vet. Human Toxicol. 45(3):147-148. <PMid:12776792>

Coutinho L.T., Costa N.D.A., Mendonça C.L.D., Afonso J.A.B., Riet-Correa F., Dantas A.F.M. \& Silva N.A.A. 2013. Intoxicação natural de bovinos leiteiros por Cestrum laevigatum (Solanaceae) no agreste de Pernambuco-Brasil. Ciênc. Anim. Bras. 14(3):352-359. <https://dx.doi.org/10.5216/cab.v14i3.13476>

Driemeier D., Irigoyen L.F., Loretti A.P., Colodel E.M. \& Barros C.S. 1999. Intoxicação espontânea pelos frutos de Xanthium cavanillesii (Asteraceae) em bovinos no Rio Grande do Sul. Pesq. Vet. Bras. 19(1):12-18. <https:// dx.doi.org/10.1590/S0100-736X1999000100003>

Furlan F.H., Lucioli J., Borelli V., Faria Junior O.O., Rebelatto S.V., Gava A. \& Traverso S.D. 2008. Intoxicação por Cestrum intermedium (Solanaceae) em bovinos no Estado de Santa Catarina. Acta Scient. Vet. 36(3):281-284. <https://dx.doi.org/10.22456/1679-9216.17302>

Gava A., Stolf L., Pilati C., Neves D.S. \& Viganó L. 1991. Intoxicação por Cestrum corymbosum var. hirsutum (Solanaceae) em bovinos no Estado de Santa Catarina. Pesq. Vet. Bras. 11(3/4):71-74.

Gava A., Stolf L., Varaschin M.S., Neves D.S., Tigre A.P. \& Lessmann F. 1996. Intoxicação por Cestrum intermedium (Solanaceae) em bovinos. Pesq. Vet. Bras. 16(4):117-120.

Kissemann K.G. \& Groth D. 2000. Plantas Infectantes e Nocivas. Vol.3. 2ª ed. BASF, São Paulo.

Lorenzi H. 2008. Plantas Daninhas do Brasil: terrestres, aquáticas, parasitas e tóxicas. $4^{a}$ ed. Instituto Plantarum de Estudos da Flora, São Paulo. 640p.

Navarro M.A., Dutra F., Briano C., Romero A., Persiane M., Freedmen J.C., Morrell E., Beigesser J. \& Uzal F.A. 2017. Pathology of naturally occurring bacillary hemoglobinuria in cattle. Vet. Pathol. 54(3):457-466. <https:// dx.doi.org/10.1177/0300985816688945><PMid:28438111>
Plumlee K.H. 2004. Hepatobiliary system, p.61-68. In: Ibid. (Ed.), Clinical Veterinary Toxicology. Mosby, St Louis.

Raposo J.B., Méndez M.C., Andrade G.B. \& Riet-Correa F. 1998. Experimental intoxication by Myoporum laetum in cattle. Vet. Hum. Toxicol. 40:275-273. $<$ PMid:9778763>

Riet-Correa F., Medeiros R.M.T., Pfister J., Schild A.L. \& Dantas A.F.M. 2009. Plants and other substances causing hepatic necrosis, p.53-65. In: Ibid. (Eds), Poisonings by Plants, Mycotoxins and Related Substances in Brazilian Livestock. Editora da Universidade Federal de Campina Grande, Campina Grande.

Riet-Correa F., Schild A.L., Méndez M.C. \& Pinheiro M.H. 1986. Intoxicação por Cestrum parqui (Solanaceae) em bovinos no Rio Grande do Sul. Pesq. Vet. Bras. 6(4):111-115.

Rissi D.R., Driemeier D., Silva M.C., Barros R.R. \& Barros C.S.L. 2007. Poisonous plants producing acute hepatic disease in Brazilian cattle, p.72-76. In: Panter K.E., Wierenga T.L. \& Pfister J.A. (Eds), Poisonous Plants: global research and solutions. CAB International, Wallingford.

Scherk M.A. \& Center S.A. 2010. Toxic, metabolic, infectious, and neoplastic liver diseases, p.1464-1477. In: Ettinger S.J. \& Feldman E.C. (Eds), Textbook of Veterinary Internal Medicine. 7th ed. W.B. Saunders, Philadelphia.

Soares E.L.D.C., Vignoli-Silva M. \& Mentz L.A. 2007. 0 gênero Cestrum L. (Solanaceae) no Rio Grande do Sul. Pesq. Sér. Bot., São Leopoldo, (58):263-282.

Tessele B., Brum J.S., Schild A.L., Soares M.P. \& Barros C.S. 2012. Sawfly larval poisoning in cattle: report on new outbreaks and brief review of the literature. Pesq. Vet. Bras. 32(11):1095-1102.<https://dx.doi.org/10.1590/ S0100-736X2012001100004>

Tokarnia C.H., Brito M.F., Barbosa J.D., Peixoto P.V. \& Döbereiner J. 2012 Plantas que sob condições naturais causam intoxicação aguda com necrose coagulativa do fígado, p.148-176. In: Ibid. (Eds), Plantas Tóxicas do Brasil para Animais de Produção. $2^{2}$ ed. Helianthus, Rio de Janeiro.

Vignoli-Silva M. 2009. 0 gênero Cestrum L. (Solanaceae) no Brasil extraamazônico. Doctoral Dissertation, Universidade Federal do Rio Grande do Sul, Porto Alegre, RS. 317p.

Wouters A.T.B., Boabaid F.M., Watanabe T.T.N., Bandarra P.M., Correa G.L.F, Wouters F., Mafessoni R.M. \& Driemeier D. 2013. Intoxicação espontânea por Cestrum intermedium em bovinos no Sudoeste do Estado do Paraná. Pesq. Vet. Bras. 33(1):47-51. <https://dx.doi.org/10.1590/S0100736X2013000100009> 